\title{
人工内耳での刺激頻度とピッチ感覚
}

\author{
榊原 淳二・竹内真理子・児嶋 久剛 \\ 伊藤 壽一・本庄 㩔・藤田 修治*

\section{Pitch Perception in Patients with Cochlear Implant}

\author{
Junji Sakakihara, Mariko Takeuchi, Hisayoshi Kojima, \\ Juichi Ito and Iwao Honjo \\ (Kyoto University) \\ Shuji Fujita \\ (Osaka Red Cross Hospital)
}

Pitch perception was investigated in four cochlear implant (CI) patients.

At first, the difference limen (D.L.) of pitch sensation conveyed by a stimulation rate was measured at each electrode in three CI subjects by the "Rate-pitch discrimination test" software program. At a fixed stimulation rate, D.L. was larger at the electrode near the round window. At most electrodes, D.L. decreased when the stimulation rate was increased. In general, D.L. was much larger than the acoustic performance in normal subjects.

Secondly, a pitch recognition test was performed in two CI patients with two fixed electrodes. Two of the 9 complex synthetic tones, with fundamental frequencies which differed successively, were inputted randomly into the speech processor with the modified "map". The pitch perception performance of the CI patients was not satisfactory, and it was thought that in speech CI patients are unable to discriminate voice pitches.

This may be explained as follows: either the CI cannot utilize the activity of neurons tuned only to pitch frequency, or the spectral pattern of complex tone is not transmitted by the CI because of the limited number of electrodes. Thus, the only coded information of pitch is a stimulation rate synchronized to voice pitch.

Key words: cochlear implant, stimulation rate, pitch perception

はじめに

コクレア社製人工内耳は，母音の第 1 ホルマ

ントF 1 扣よび第 2 ホルマントF 2 の周波数か

ら蝸牛内に挿入された多数の電極のらち，2 箇 所を選択して刺激する方式である。本方式は他
の方式に比して母音の認識に有利であり ${ }^{1)}$ ，我 我の経験でも一連の電極が蝸牛基底回転に十分 挿入された症例では母音弁別は $80 \%$ 程度と良好 であり2)，䆍者が社会復帰する上で大さな福音 となっている. 
一方, 本人工内耳では音声のピッチ周期で電 極を発火させることで, 基本周波数 $\mathrm{F} 0$ を聴神 経に伝えるとされているが，患者が刺激頻度の 違いに対して鋭敏であれば，音階の并別は容易 のはずと考えられる. しかし, 試みに簡単な童 謡のメロディを数名の母音弁別良好な人工内耳 症例に聴かせたところ音階を聞き取ることが全 くできなかったことから，人工内耳患者のピッ チ弁別能はそれ汪ど鋭敏でないと考えられた ${ }^{31}$. そこで, 人工内耳患者が刺激頻度の違いをどの 程度ピッチの違いとして知覚し得るかを調べ, 基本周波数すなわち音声ピッチを聴神経に伝え ようとする試みが語音の認知にどの程度有益か を検討した。

\section{方法}

母音弁別が汪ぼ $80 \%$ 以上と良好な人工内耳患 者 4 名（表 1 ）で, 以下に述べる 2 通りの方法 でのピッチ弁別能を評価した。

1 ) 電極 1 箇所を発火させたとさのピッチ 并別

症例 1 〜 3 人工内耳患者で電極 1 箇所ずつ を50, 100, $200 \mathrm{~Hz}$ の 3 通りの刺激頻度で発火 させ, 刺激頻度を $1 \mathrm{~Hz}$ ずつ増加させたとさピ ッチの変化が知覚されはじめた值を調べ, 各周 波数での心理物理学的な弁別閾値 (difference limen, 以下 D.L. と略す) を求めた。刺激電 流量は, 個々の電極の最大快適レベルの $80 \%$ と し, 回数は各周波数で 1 回ずつとし上昇法で行 った.

さらに症例 4 の人工内耳患者で, 刺激電極を 20 番（蝸牛頂寄りで最も低い周波数を担当する 電極) に固定し, 刺激頻度を $90 \mathrm{~Hz}$ から $220 \mathrm{~Hz}$
まで $10 \mathrm{~Hz}$ 和さに変化させた時の弁別閾値 D.L.を同様の方法で調べ，刺激頻度と D.L. の関係を検討した.

2 ）電極 2 箇所を発火させたとさのピッチ 弁別

本人工内耳では, 通常 2 箇所の電極が淘湆同 時に発火する設定となっている。そこで，これ に近い条件でのピッチ弁別能を調べた.

症例 1 および 4 で使用電極を 10 番と 18 番の 2 箇所に設定した。これは母音/e/ 入力時の発火 電極に注湆相当する.周波数の割当ては 0 ～595 $\mathrm{Hz}$ を18番とし，596〜 $4000 \mathrm{~Hz}$ までを10番とし た. 次に基本周波数が異なる 9 個の合成音 $(110,125,141,156,180,195,211,227,242$ $\mathrm{Hz})$ の中からランダムに異なる 2 音をスピーチ ・プロセッサを介して入力し，これら 2 箇所の 電極を異なる基本周波数の頻度で発火させて,

表 2 合成音の周波数構成

\begin{tabular}{l|l|l}
\hline \hline & 基本周波数 & 倍音周波数 \\
\hline 1 & $110 \mathrm{~Hz}$ & $1578 \mathrm{~Hz}$ \\
2 & 125 & 1539 \\
3 & 141 & 1593 \\
4 & 156 & 1601 \\
5 & 180 & 1593 \\
6 & 195 & 1539 \\
7 & 211 & 1671 \\
8 & 227 & 1578 \\
9 & 242 & 1687
\end{tabular}

電極 10 番の発火に必要な周波数成分は，基本周 波数の整数倍で互いに近い值とした. その周波 数は刺激の頻度とは直接関係しない. 各周波数 成分の振幅は同一とした。

表 1 人工内耳症例

\begin{tabular}{c|c|c|c|c}
\hline \hline 症 例 & 埋め込又時年㱓 & 性別 & 難聴の原因疾患 & 失聴期間 \\
\hline 1. & 55 & 男 & 頭部外傷 & 1 年 7 力月 \\
2. & 66 & 男 & 頭部外傷 & 1 年 8 力月 \\
3. & 63 & 男 & 内耳炎 & 5 年 \\
4. & 55 & 女 & 突発性難聴 & 9 年
\end{tabular}


2 音の内どちらが高く聞こえるかを指摘させた． 合成音の組み合わせ毎にそれぞれ10回ずつ呈示 し，正答数を調べた．表 2 に合成音の一覧を示 す. 電極 10 番を発火させるための周波数成分は, 基本周波数の整数倍とし，かつ各合成音で近い 值になるように設定した。

\section{結 果}

1 ）電極 1 箇所を発火させた場合のピッチ 弁別

図 $1 \mathrm{a}, \mathrm{b}, \mathrm{c}$ にそれぞれ症例 $1,2,3$ の各電 極での D.L.の值を示す．電極 1 箇所を発火さ せる方法では, 全症例で $100 \mathrm{~Hz}$ 刺激に対して その 1.5 倍以上刺激頻度を高めてょらやくピッ チの違いを指摘でさた。一般に電極が蝸牛底に 近い程, ピッチ弁別能が低下する傾向が認めら れた。 また各電極についてみると, 刺激頻度が 低い程 D.L. の值は大きく，ピッチ弁別能が不 良となるものが多かった。

図 2 は, 症例 4 で電極を 20 番に固定した場合 の D.L. の值を並べたものである. 同一電極で は，刺激頻度が低い程ピッチ弁別能が不良とな る傾向がより明らかとなった. 刺激頻度の变化 に対する D.L. は，最良でも $10 \sim 20 \%$ と正常者 が音刺激で行った場合のピッチ弁別能に比し て, 1 桁以上大きな值であった。

2 ) 電極 2 箇所を発火させた場合のピッチ 升別

図 $3 \mathrm{a}$ ，拈よび図 $3 \mathrm{~b}$ 亿症例 1 と 4 での結果 をとれぞれ示す。陰影部は10回のらち 2 回以上 誤りがあった組み合わせである，各症例とも電 極 2 箇所を発火させた場合でも，隣合った周波 数の 2 音の并別の多くは不確実であった。また 症例 1 では，1オクターブ近く離れた音でもピ ッチ弁別が不確実となる場合がみられ，刺激頻 度の違いがピッチの違いとして必ずしも十分に は知覚され得ないことが明らかとなった。

\section{考按}

聴神経ニューロンの音刺激に対する応答とサ イン波電流刺激に対する応答が大きく異なる点 は，純音刺激では明確な特徵周波数がみられる
のに対し，電気刺激では応答野は浅い皿状を呈 し周波数選択性はないに等しいことが挙げられ る4). また，各ニューロン間での周波数選択性 の違いも殆ど認められない.ダイナミック・レ ンジは音刺激が $30 \sim 50 \mathrm{~dB}$ あるのに対し, 電気 刺激では電流量から換算して $5 \mathrm{~dB}$ から最大 20 $\mathrm{dB}$ と狭い5)。さらに重要な点は, 音刺激では 多数のニューロンから同時に入力された情報を 聴覚系が総合的に処理できるのに対し, 電気刺 激では多チャンネル方式であっても電極間の干 渉のために同時刺激できる電極が数個に制限さ れるため, 上位聴覚中枢でのいわゆる feature extraction 機能, 例兄ば高次の倍音成分 (harmonics) からピッチを抽出する機能などが十分 発揮でさない可能性が挙げられる.

以上の相違を踏ま光, 人工内耳, 特に蝸牛内 多チャンネル方式で伝えられるピッチについて 検討してみた。

まず音刺激では，音声ピッチをコード化する 方法として, (1)特徵周波数が基本周波数に一致 するニューロンが活動してピッチを伝えるとい ら説，(2)ニューロンの周期的発火 (phase-lock) がピッチを伝えるとする temporal theory, (3) 多数のニューロンの発火パターンからピッチが 抽出されるとする pattern recognition theory の 3 通りがある. 一方, 人工内耳では刺激部位 が基本周波数より高い周波数を担当する基底回 転に限られること，また同時刺激できる電極が 限られることから，ピッチ情報を電気刺激を介 して伝える方法としては，(2)に基ついた方法が 採られることが多い.コクレア社製人工内耳で も，音声の基本周波数を抽出して刺激頻度とし ている.

この方式によるピッチ情報伝達にはいくつか の問題点がある.第一は, 例えば特徵周波数が $1 \mathrm{kHz}$ 以上のニューロンを $0.3 \mathrm{kHz}$ 以下の低い 刺激頻度で刺激した場合, ピッチ情報として中 枢で有効に処理され得るかという点である。

Shamma ${ }^{67)}$ は, 蝸牛神経核での lateral inhibition モデルで, 聴神経ニューロソの活動が自己 


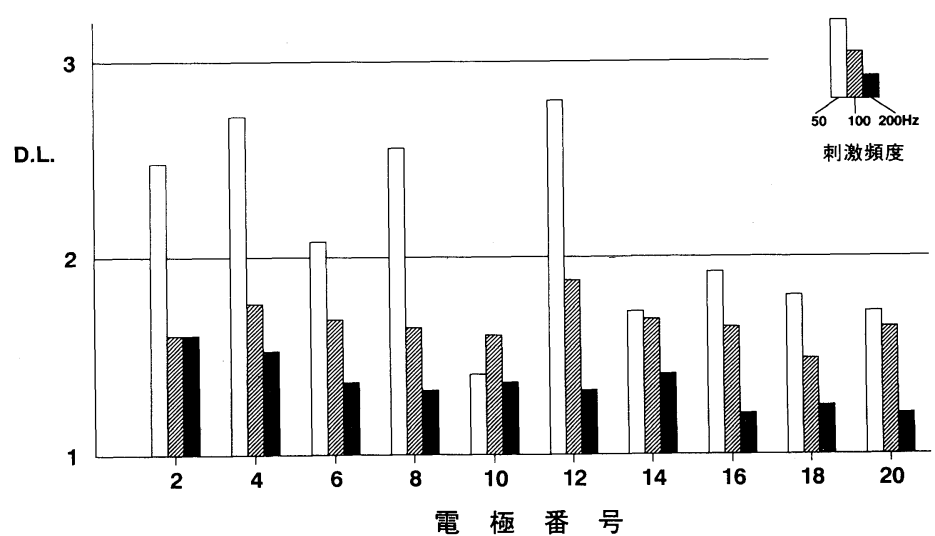

図 $1 \mathrm{a}$

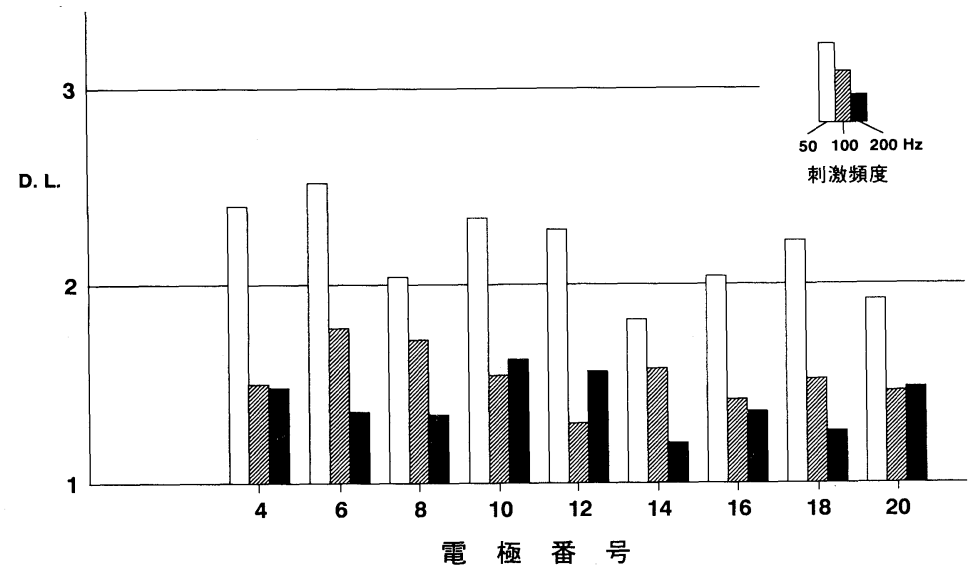

圀 $1 \mathrm{~b}$

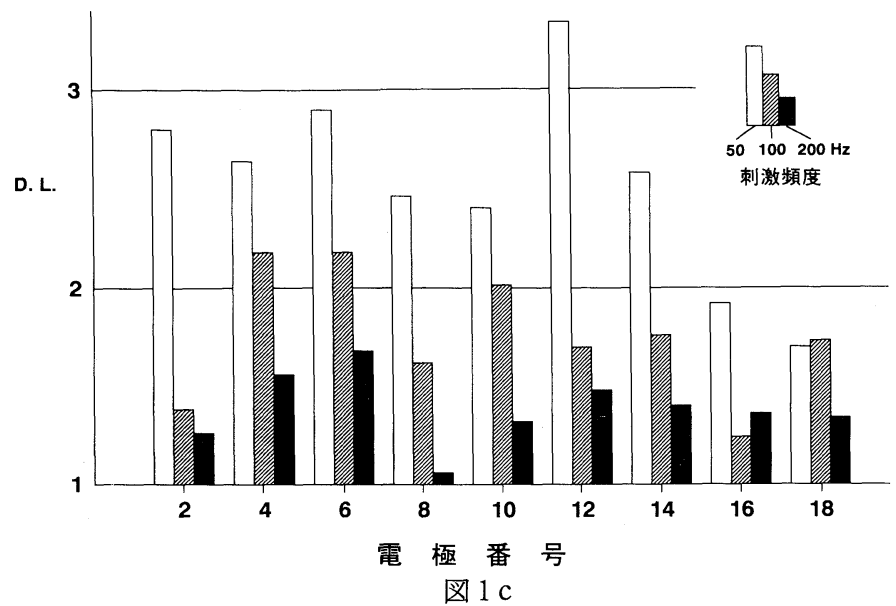

図 1 電極 1 箅所を発火させた場合のピッチ弁別成績

基準の刺激頻度を $50,100,200 \mathrm{~Hz}$ とし, 症例 1，2，3の各電極で の弁別間値の結果を $\mathrm{a}, \mathrm{b}, \mathrm{c}$ そそれぞれ示す。 


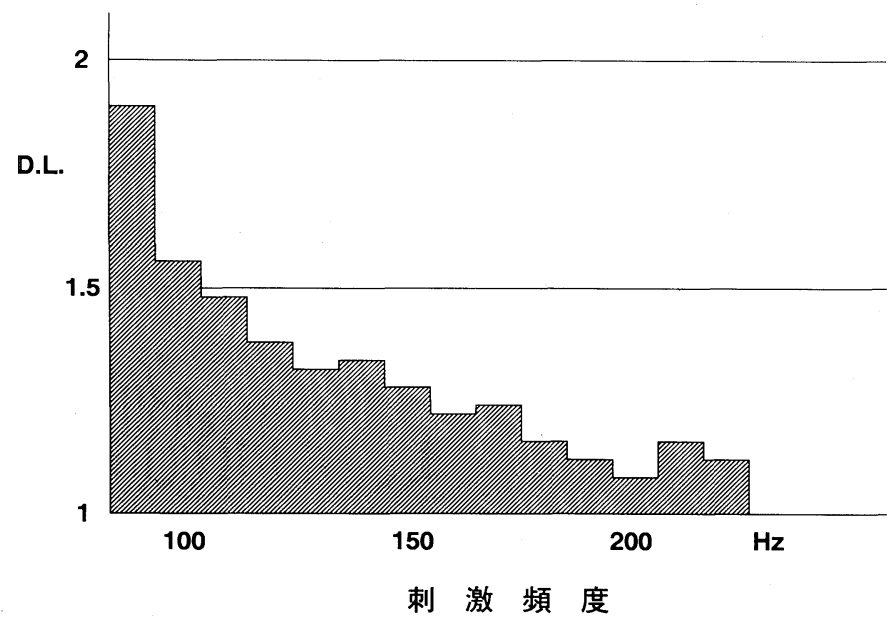

図 2 症例 4 の電極 20 番でのピッチ弁別成績

電極を 20 番に固定し, 基準周波数を $10 \mathrm{~Hz}$ 毎に増加した場合のピッチ 弁別をグラフに示す.

\begin{tabular}{|c|c|c|c|c|c|c|c|c|c|}
\hline $\mathrm{Hz}_{\mathrm{Hz}} \mathrm{Hz}$ & 110 & 125 & 141 & 156 & 180 & 195 & 211 & 227 & 242 \\
\hline 110 & & 4 & 10 & 8 & 9 & 10 & 8 & 10 & 10 \\
\hline 125 & & & 6 & 10 & 10 & 10 & 10 & 10 & 10 \\
\hline 141 & & & & 10 & 10 & 10 & 9 & 10 & 9 \\
\hline 156 & & & & & 10 & 10 & 10 & 8 & 17. \\
\hline 180 & & & & & & 9 & 8 & 9 & 7 \\
\hline 195 & & & & & & & 5 & 7. & 6. \\
\hline 211 & & & & & & & & ? & 7 \\
\hline 227 & & & & & & & & & 5 \\
\hline
\end{tabular}

図 $3 a$

\begin{tabular}{|c|c|c|c|c|c|c|c|c|c|}
\hline $\mathrm{Hz}$ & 110 & 125 & 141 & 156 & 180 & 195 & 211 & 227 & 242 \\
\hline 110 & & 9 & 10 & 10 & 10 & 10 & 10 & 10 & 10 \\
\hline 125 & & & ? & 10 & 10 & 10 & 10 & 10 & 10 \\
\hline 141 & & & & 8 & 9 & 10 & 10 & 10 & 10 \\
\hline 156 & & & & & 7. & 10 & 10 & 10 & 10 \\
\hline 180 & & & & & & 8 & 9 & 10 & 10 \\
\hline 195 & & & & & & & 6 & 9 & 10 \\
\hline 211 & & & & & & & & in. & 10 \\
\hline 227 & & & & & & & & & 5. \\
\hline
\end{tabular}

図 3 b

図 3 電極 2 箇所を発火させた場合のピッチ弁別成績 電極を 10 番と 18 番に設定後, 合成音の各組み合わせ毎にそれぞれ 10 回 呈示し，正答数をまとめた．陰影部は 2 回以上誤りがあった組み合わ せを示す。 
の特徵周波数に phase-lock しているものだけ が中枢で acceptされる可能性を示して扣り， これが事実だとするとコクレア社製人工内耳で はピッチ情報が中枢に伝達されないことになる．

第二には, 単一ニューロソが音の強さの違い を発火頻度でュード化していることから考えて， 刺激頻度の違いをピッチの違いとしてだけでな く音の強さの違いとして認知する可能性である. これは, 人工内耳患者にピッチ弁別能の聴覚心 理学的検査を行う際, 注意を要する点である.

第三は, 刺激頻度が同じでも蝸牛の刺激部位 によって知覚されるピッチが異なる点である8). 基底回転寄りでは高く, 頂回転寄りでは低く知 覚されるため, ホルマントの高低によって電極 を選択するコクレア社の方式では，同じ基本周 波数でも各母音でピッチが異なって知覚される 可能性がある.

今回我々は 4 名の人工内耳患者で, 電極を固 定して刺激頻度を変化させたときのピッチ弁別 能を評価した結果，周波数の弁別閾は正常者の 音刺激での弁別閾よりも大きく劣っていた。こ れは，上記の問題点を反映した結果と推察され る. この成績から考えて, 本人工内耳によるピ ッチ弁別は少なくとも会話音域では不完全であ り，刺激頻度の違いでピッチを伝えようとする 意義は小さいことが示唆された。

聴覚生理上, 可能な限り蝸牛頂近くまで電極 を挿入すれば，ピッチ弁別が向上するものと推 測される. 刺激頻度の違いに対して, 正円空寄 りの電極よりも蝸牛頂寄りの電極の方が鋭敏で あった事実もこれに符合する。しかしながら蝸 牛頂への電極挿入が不可能な現在, ピッチを伝 える試みが語音の認知向上にどの程度寄与して いるのかには疑問が残る. 本人工内耳でも大ま かなピッチ弁別は可能であった（図 2 ）。乙か し一般に話声のピッチの変動幅は10～20\%より 小さく, 今回得られた D. L. 值から考えて, 人 工内耳患者はこの変動を十分に捉えていない可 能性が高いと考えられた。

\section{まとめ}

人工内耳患者のピッチ弁別能を評価した結果, 1. 刺激頻度の違いをピッチの違いとして十 分認知できないことがわかった。

2 . 基本周波数を刺激頻度に用いる意義は少 ないものと推測された.

な抒, 本論文の要旨は第91回日本耳鼻咽喉科学会 総会で口演した.

\section{文献}

1）船坂宗太郎, 湯川久美子, 高橋 整, 他 : 22Channel Cochlear Implant の聴取能に関する一 考察一刺激方式の異なる 2 症例の音響生理学 的背景一. 日耳鼻 $91: 177 \sim 184,1988$.

2）伊藤壽一, 土師知行, 川野通夫, 他: 人工内耳 手術とリハビリテーション。耳鼻臨床 81 ： 1563 1568, 1988.

3) Townshend B, Cotter N, Compernolle D, et al : Pitch perception by cochlear implant subjects. J Acoust Soc Am 82 : 106 115, 1987.

4) Kiang NYS and Moxon EC : Physiological considerations in artificial stimulation of the inner ear. Ann Otol Rhinol Laryngol 81 : 714 $\sim 730,1972$.

5) Hochmair ES and Hochmair-Desoyer IJ : Aspects of sound signal processing using the Vienna intra- and extracochlear implants. Cochlear Implants (ed by Schindler RA and Merzenich MM). pp 101 110, Raven Press, New York, 1985.

6) Shamma SA : Speech processing in the auditory system I ; the representation of speech sounds in the responses of the auditory nerve. J Acoust Soc Am $78: 1612 \sim 1621$, 1985.

7) Shamma SA : Speech processing in the auditory system II; lateral inhibition and the central processing of speech evoked activity in the auditory nerve. J Acoust Soc Am 78 : 1622 $\sim 1632,1985$. 
8) Eddington DK : Speech discrimination in deaf subjects with cochlear implants. J Acoust Soc Am 68 : 885 891, 1980.

/原稿受付: 平成 2 年 7 月 23 日 原稿採択: 平成 2 年 8 月 13 日 別刷請求先 : 榊原淳二

于606 京都市左京区聖護院川原町54

京都大学医学部耳鼻咽喉科学教室 